\title{
PENGARUH INTELLECTUAL CAPITAL PADA IBU RUMAH TANGGA TERHADAP KEBERHASILAN PENDIDIKAN ANAK DENGAN SOCIAL CAPITAL SEBAGAI VARIABEL MODERATING
}

\author{
Fika Azmi* \\ Mirasanti Wahyuni \\ Sri Imaningati \\ STIE Bank BPD Jateng \\ *fixs2002@gmail.com
}

\begin{abstract}
Child education is very important to note because children or young generation is the next generation of nation that will soon be built nation building. Parents must pay attention to the quality of children's education. Mother is the first teacher for a child and also the greatest motivator for child development. Therefore, the mother is expected to encourage the success of children's education. A housewife who is an unemployed mother has greater time and opportunity to make it happen. It takes capital to do that. Individual characteristics of the intellectual capital of the housewife who is the greatest driver for the success of children's education. And this encouragement will increase as it happens by the increase in social capital owned by housewives. This study will accommodate the intellectual capital owned by housewives to the success of children's education with social capital as a moderate variable. Statistical test tool used is linear regression. The subject is the people of Central Semarang. Samples were taken by random sampling. The data used are primary data collected by questionnaire. The result of Social Capital has an effect on the success of children's education and intellectual capital expressed as excluded variable
\end{abstract}

Keywords: Success of Children's Education, Intellectual Capital housewife, Social Capital. 


\section{PENDAHULUAN}

Dewasa ini pendidikan anak menjadi bahasan khusus. Keberhasilan anak berkenaan dengan pendidikannya merupakan kebanggaan orangtua. Keberhasilan anak dalam pendidikan juga merupakan keberhasilan orangtua dalam mendidik, karena menurut Salwinsah, 2011, keberhasilan pendidikan anak dipengaruhi oleh peranan orangtua, sekolah dan guru. Walaupun ukuran keberhasilan sebenarnya sangatlah relatif, namun beberapa penelitian mencoba membuat ukuran seperti Triana (2013), mengukur keberhasilan pendidikan karakter, dan Andi (2012) mengukur keberhasilan pendidikan ilmu pengetahuan formal.

Peran orang tua sangatlah penting. Karena dalam satu hari yang berdasarkan hitungan jam, lebih banyak anak berinteraksi dengan orangtua daripada dengan guru di sekolah terutama dengan ibu. Apalagi jika berkaitan dengan ibu yang bukan merupakan ibu pekerja, atau yang biasa disebut dengan ibu rumah tangga. Janganlah menyerahkan pendidikan anak sepenuhnya pada guru. Sedangkan Guru di sekolah sangatlah berharap bantuan orangtua dalam ikut menanamkan ilmu dan karakter pada anak didik. Orangtua sangat diharapkan perannya terutama ibu. Beberapa peran yang dapat dilakukan seperti, menyediakan tempat khusus untuk belajar, mendisiplinkan waktu belajar, turut memantau diselesaikannya PR dan tugas, turut memantau penyelesaian materi, serta menegaskan kembali penanaman pendidikan karakter yang sudah dilakukan di sekolah. Agar dapat melakukan itu semua, ibu rumah tangga juga perlu mengembangkan diri agar mampu mengikuti dan menyesuaikan dengan perkembangan jaman. Ibu rumah tangga harus memperbarui pengetahuannya dengan cara menambah bacaan, mengembangkan ketrampilannya dengan cara mempraktekkannya, dengan banyak membaca akan lebih inovatif, sehingga dengan berbekal itu semua ibu rumah tangga akan lebih mudah menyelesaikan tugas, termasuk diantaranya membantu proses pendidikan dan pembelajaran anak. Komponen-komponen di atas (pengetahuan, ketrampilan, kemampuan inovasi, penyelesaian tugas) merupakan komponen Human Capital. Dan Human Capital merupakan salah satu Indikator dari Intellectual Capital.

Perkembangan lingkungan ternyata
juga berefek pada hal-hal yang mempengaruhi keberhasilan pendidikan anak. Termasuk didalamnya adalah Social Capital. Social Capital merupakan kemampuan manusia untuk menjadi mahluk sosial, William (2001). Mahluk sosial dalam kaitannya dengan interaksi antar manusia untuk memperoleh keuntungan berupa informasi yang diperlukan. Seorang ibu rumah tangga, walaupun hanya keluar rumah karena urusan keluarga, tapi jika mempunyai relasi banyak, dalam artian hubungan sosialnya baik, maka akan lebih mudah memperoleh berbagai informasi, salah satunya informasi tentang pendidikan anak. Ia akan lebih mudah memperoleh informasi bagaimana mendidik anak yang baik, pendidikan macam apa yang diperlukan anaknya sampai dengan informasi tentang sekolah-sekolah favorit sebagai pertimbangan sekolah anaknya. Efeknya adalah, ibu rumah tangga tersebut dapat mendidik anaknya dengan lebih baik dan anaknya dapat memperoleh sekolah seperti yang dicita-citakannya karena strategi sekolah sudah dibuat bersama ibu dan anak. Dengan demikian hubungan sosial yang baik dapat meningkatkan pengaruh modal pengetahuan ibu rumah tangga terhadap keberhasilan pendidikan anak.

Penelitian ini di lakukan di daerah Semarang Tengah. Dimana Wilayah Semarang Tengah adalah area perniagaan. 
Disana terdapat tiga kelompok perniagaan, meliputi (1) pertokoan di daerah Jalan Pemuda yang dimiliki oleh pedagang dengan modal relatif besar, (2) pertokoan di daerah Jalan Kauman, yang kebanyakan pemiliknya berdarah campuran Cina-IndiaArab, dengan modal menengah, (3) dan daerah pasar Johar. Dampak dari tiga area perniagaan ini mengakibatkan masyarakat asli Semarang tengah cenderung bermata pencaharian sebagai pedagang. Orangtua pedagang kemungkinan besar juga menginginkan anaknya menjadi pedagang. Untuk menjadi pedagang maka tidak diperlukan sekolah tinggi.

Selain hal tersebut, ternyata sebagian besar ibu di daerah Semarang Tengah merupakan ibu rumah tangga (53\%), selebihnya mengurusi usaha sendiri $(37 \%)$ dan pekerja pada orang lain (10\%). Hal ini menimbulkan pertanyaan, apakah peran ibu rumah tangga mempengaruhi keberhasilan pendidikan anak.

Tujuan dari penelitian ini adalah untuk mengetahui dan menguji secara empiris pengaruh Intellectual Capital pada Ibu Rumah Tangga terhadap Keberhasilan Pendidikan Anak, dengan Social Capital sebagai variabel moderating. Harapan dari hasil penelitian ini adalah diketahuinya faktor karakteristik ibu rumah tangga yang dapat meningkatkan kemungkinan keberhasilan pendidikan anak. Dan tentu saja apabila pengujian secara empiris bahwa Social Capital mempengaruhi "hubungan pengaruh", maka ibu rumah tangga juga perlu meningkatkan hubungan sosialnya.

\section{KERANGKA TEORITIS Definisi Ibu Rumah Tangga (IRT)}

Istilah Ibu Rumah Tangga sering kita dengar. Beberapa orang menganggap bahwa IRT bukanlah pekerjaan. Beberapa orang lainnya menganggap bahwa itu adalah kodrat yang harus dijalani oleh seorang wanita. Menurut Kamus Besar Bahasa Indonesia, IRT dapat diartikan sebagai seorang wanita yang mengatur penyelenggaraan berbagai macam pekerjaan rumahtangga , atau IRT merupakan seorang istri (ibu) yang hanya mengurusi berbagai pekerjaan dalam rumah tangga (tidak bekerja di kantor), (Superi, 2013).

Dari definisi di atas dapat disimpulkan bahwa IRT adalah seorang perempuan atau wanita yang telah menikah, tidak bekerja pada orang lain di luar rumah atau tidak bekerja di instansi di luar rumah. IRT hanya mengerjakan pekerjaan yang berkaitan dengan kerumahtanggaan. Seperti melayani suami, merawat anak, memasak, menyiapkan pakaian, membersihkan rumah, mengantar anak sekolah dan sebagainya yang intinya IRT tidak mempunyai penghasilan sendiri diluar pemberian suami. Walaupun beberapa fungsi di atas dapat digantikan oleh Asisten Rumah Tangga (ART) alias Pembantu Rumah Tangga (PRT).

Sebenarnya tugas seorang IRT tidaklah sesederhana itu. Bahkan sebenarnya seorang IRT telah menjalankan banyak fungsi manajerial disamping kodrat alami sebagai seorang istri dan ibu. Adapun fungsi seorang IRT meliputi :

1. Sebagai Istri

Sebagai istri, seorang IRT harus melayani suami dalam berbagai aspek. Mulai dari tempat tidur, menyiapkan pakaian, menyiapkan makan, menemani ngobrol, tempat curhat dan berbagai fungsi yang bersifat individual dan tertutup sampai dengan menemani dalam berbagai pertemuan yang menuntut istri ikut.

\section{Sebagai Ibu}

Seorang IRT dapat dipanggil ibu ketika sudah melahirkan dan mengurus anak. Bahkan melahirkan anak ini dianggap wajib sebagai fungsi meneruskan silsilah keluarga. Seorang IRT harus mampu merawat 
anaknya dengan baik. Mulai dari memandikan, menyediakan makan dan pakaian, menemani tidur, sampai menjadi tempat curhat ketika anak-anak sudah menginjak masa remaja.

3. Sebagai Manajer Keuangan Ibu biasanya yang mengatur keluar masuknya kas di rumah tangga. Walaupun tidak semua IRT memegang kas besar tetapi kecenderungan seorang IRT pasti memegang urusan kas kecil. Dana bulanan yang ia terima dari suami, akan di kelola sedemikian rupa sehingga cukup untuk sebulan. Seperti dana untuk membayar semua urusan anak sekolah, membayar les, membayar listrik-air-telpon, membayar pembantu, membayar belanja bulanan dan belanja harian, bensin, pemeliharaan rumah dan mobil, sumbangan sosial, iuran masyarakat, sampai bantuan untuk keluarga besar. IRT yang baik adalah yang mampu mengelola keuangan dengan pas, artinya cukup untuk satu bulan dan diusahakan terjadi surplus.

4. Sebagai Guru

Seorang IRT harus mampu membantu proses pembelajaran yang terjadi pada anaknya. Dalam bahasa Jawa, Guru diistilahkan sebagai "digugu dan ditiru", artinya yang jadi panutan dan ditauladani. Sehingga seorang IRT harus mampu menunjukkan fungsi dan peran yang bisa dijadikan panutan dan diteladani oleh anakanaknya. Fungsi guru juga tercermin dari bantuannya terhadap proses pembelajaran anak di sekolah. Seperti membantu belajar dengan mendiktekan pertanyaan-pertanyaan untuk persiapan ulangan, membantu membuat PR dan juga membantu membuat tugas keterampilan.

5. Sebagai Supir Pribadi

Jika dalam keluarga tidak mempunyai supir, dan suami tidak memungkinkan karena alasan pekerjaan, maka fungsi IRT juga sebagai supir pribadi. Antar jemput anak sekolah, kegiatan extra, les dan aktivitas anak lainnya. Pergi untuk keperluan sendiri maupun berbelanja akan menyetir sendiri. Bahkan ke bandara menjemput mertua yang berkunjung pun menjadi urusannya.

\section{Sebagai Koki}

Sebagai koki, maka IRT harus mampu menyusun menu yang menjadi kesukaan dan kebutuhan suami dan anaknya. Bahkan kesukaan mertua, saudara, teman anaknya dan teman suami yang sering berkunjung ke rumah juga harus masuk ke dalam memorinya. Termasuk pantangan masingmasing orang. Seperti contoh IRT harus mampu menyusun menu sedemikian rupa jika suami alergi sea food, anak sulung suka sekali udang tapi alergi susu sapi, bisanya susu soya, sedangkan anak bungsu tidak suka makan sayur (dan sayur harus tetap dimakan anak tersebut).

7. Sebagai Design Interior dan eksterior rumah

Sebagai Design Interior seorang IRT harus mampu menata rumahnya. Mengganti perabot jika usang atau sudah membosankan. Mengkombinasikan perabot dengan warna dan bentuknya. Serta membuat rumah selalu segar dan homey.

8. Sebagai Dokter

Sebagai dokter, seorang IRT harus tahu dan selalu memantau kesehatan suami dan anaknya. Cuaca yang mempengaruhi kesehatan harus ditanggulangi dengan menyiapkan makanan bergizi tinggi ataupun tambahan asupan vitamin. IRT harus tahu ketika kondisi suami atau anak sedang drop atau fit. Dan ibu yang bertanggungjawab untuk membawa ke dokter jika ada yang sakit dan sekaligus merawatnya dengan memberikan obat ataupun menyediakan makanan yang dianjurkan dokter.

9. Sebagai Public Relation

Seorang IRT harus mampu menjadi PR keluarga. IRT yang biasanya lebih tahu terlebih dahulu tentang kabar tetangga yang 
sakit, melahirkan, ulang tahun maupun punya hajatan. Dan apabila tidak bisa hadir berdua dalam acara-acara tersebut, maka IRT yang mewakili suami dan keluarga untuk hadir. Fungsi PR juga tercermin dari kehadirannya mendampingi suami dalam acara-acara tertentu. Bertemu dengan kolega suami, dengan istri kolega suami maupun rekan-rekan suami yang lain. Kemampuan menempatkan diri, dan mensejajarkan kemampuan berbicara maupun menanggapi topik pembicaraan merupakan modal utama.

Dari fungsi di atas terlihat bahwa begitu kompleksnya sebenarnya fungsi maupun tugas seorang IRT. Beberapa wanita pekerja mungkin akan mengatakan bahwa mereka menjalankan ke sembilan fungsi tersebut dan juga bekerja. Namun jika salah satu fungsi tersebut atau beberapa fungsi tersebut tidak sukses dilakukan, maka wanita pekerja akan lebih banyak memperoleh permakluman dari pada IRT. Olehkarenanya tidak mengherankan jika dewasa ini IRT dituntut untuk mempunyai intelektualitas yang tinggi, agar kesembilan fungsi di atas dapat dilakukan dengan baik dan benar.

\section{Definisi Intellectual Capital (Modal Intelektual) pada Ibu Rumah Tangga}

Stewart (1997) mendefinisikan intellectual capital sebagai "packaged useful knowledge" yang merupakan sumber daya berupa pengetahuan yang tersedia pada perusahaan yang menghasilkan aset bernilai tinggi dan manfaat ekonomi di masa mendatang bagi perusahaan. Edvinsson dan Malone (1997, hal. 358) memperluas definisi IC untuk "knowledge that can be coverted into value" yang berarti pengetahuan yang dapat dikonversi menjadi nilai. Penelitian yang dilakukan oleh Stewart (1997), Edvinsson dan Malone (1997), dan Bontis (2000) mempunyai kesamaan klasifikasi komponen IC. Menurut klasifikasi mereka, IC perusahaan dalam arti luas terdiri dari :

1. Human Capital (HC)

2. Structural Capital (SC)

3. Customer Capital (CC).

Jika dikaitkan dengan IRT, maka

Intellectual Capital yang dipakai adalah berkaitan dengan Human Capital. Menurut Bontis (2004) human capital adalah kombinasi dari :

1. pengetahuan, yang diukur dengan pendidikan (Sarjana dan bukan sarjana sebagai variabel dummy)

2. skill, yang diukur dengan pengalaman lamanya berumahtangga

3. kemampuan melakukan inovasi

4. kemampuan menyelesaikan tugas.

\section{Definisi Social Capital (Modal Sosial)}

Modal sosial mulai diperkenalkan pada awal 1980-an oleh seorang sosiolog Perancis bernama Pierre Bourdieu (Alfiasari, 2013). Modal sosial mulai dikenal khalayak luas semenjak dipublikasikannya tulisan sosiolog asal Amerika bernama James Coleman yang berjudul Social Capital in The Creation of Human Capital. Pada awal munculnya konsep ini, modal sosial didefinisikan sebagai sumberdaya baik yang aktual maupun maupun potensial yang dimiliki seseorang berkat adanya jaringan hubungan secara kelembagaan yang terpelihara dengan baik (Syahra et al.2000). Bourdieu menekankan bahwa modal sosial yang dibentuk oleh jaringan hubungan, tidak begitu saja ada secara alami (natural given), namun harus diusahakan. Bourdieu tertarik pada pengembangan konsep modal sosial sebagai sumberdaya bagi modal ekonomi seseorang (economic capital)

Stone dan Hughes (2002) melambangkan modal sosial sebagai sebuah perekat di antara anggota masyarakat untuk menjaga kebersamaan munitas/ masyarakat 
yang dilambangkan dengan jaringanjaringan dalam hubungan sosial, yang dicirikan oleh adanya norma kepercayaan dan hubungan timbal balik yang mengarahkan masyarakat untuk mencapai kepentingan bersama.

Menurut Stone dan Hughes (2002), modal sosial mempunyai dua ukuran utama yaitu :

1. Jaringan Sosial (Networks) Jaringan sosial dilihat dengan menggunakan beberapa ukuran yaitu:

a. ikatan informal yang dikarakteristikan dengan adanya kepercayaan dan hubungan timbal balik yang lebih familiar dan bersifat personal seperti pada ikatan pada keluarga, pertemanan, bertetanggaan

b. ikatan yang sifatnya lebih umum seperti ikatan pada masyarakat setempat, masyarakat umum, masyarakat dalam kesatuan kewarganegaraan. Ikatan ini dikarakteristikkan dengan adanya kepercayaan dan hubungan timbal balik yang sifatnya umum

c. ikatan kelembagaan yang dikarakteristikkan dengan adanya kepercayaan dalam kelembagaan yang ada. Misalnya pada ikatan dalam sistem kelembagaan dan hubungan kekuasaan.

2. Karakteristik Jaringan Sosial (Networks Characteristics).

Karakteristik jaringan sosial (Network Characteristics) dapat dilihat dari tiga karakteristik yaitu :

a. bentuk dan luas (size and extensiveness)

b. kerapatan dan ketertutupan (density and closure)

c. keragaman (diversity)

Karakteristik bentuk dan luas meliputi : jumlah hubungan informal yang terdapat dalam sebuah interaksi sosial, jumlah tetangga mengetahui pribadi seseorang dalam sebuah sistem sosial, dan jumlah kontak kerja.

Kerapatan dan ketertutupan sebuah jaringan sosial dapat dilihat misalnya dengan seberapa besar sesama anggota keluarga saling mengetahui teman-teman dekatnya, diantara teman saling mengetahui satu sama lainnya, masyarakat setempat saling mengetahui satu sama lainnya.

Keragaman, jaringan sosial dikarakteristikkan misalnya dari keragaman etnik teman, dari perbedaan pendidikan dalam sebuah grup atau dari pencampuran budaya dalam wilayah setempat.

\section{Definisi Keberhasilan Pendidikan Anak.}

Menurut Salwinsah (2012), pendidikan anak merupakan hal terbesar yang selalu diutamakan oleh para orang tua. Saat ini masyarakat semakin menyadari pentingnya memberikan pendidikan yang terbaik kepada anak-anak mereka sejak dini. Untuk itu orang tua memegang peranan yang sangat penting dalam membimbing dan mendampingi anak dalam kehidupan keseharian anak. Sudah merupakan kewajiban para orang tua untuk menciptakan lingkungan yang kondusif sehingga dapat memancing keluar potensi anak, kecerdasan dan rasa percaya diri. Dan tidak lupa memahami tahap perkembangan anak serta kebutuhan pengembangan potensi kecerdasan dari setiap tahap.

Ukuran keberhasilan pendidikan anak sangatlah penting. Mengingat tujuan orang tua mendidik dan menyekolahkan anak berbeda antara satu dengan lainnya. Juga terkait dengan cita-cita anak sendiri yang jelas akan berbeda antara anak yang satu dengan anak yang lain. Maka harus ada ukuran relatif yang dapat mengakomodasi semuanya. 
Keberhasilan pendidikan anak meliputi :

a. Keberhasilan program pendidikan ilmu pengetahuan

Adapun keberhasilan pendidikan ilmu pengetahuan diukur dengan (Andi 2012):

1. Selalu diterima di sekolah yang diinginkan

2. Tidak pernah tinggal kelas

3. Nilai selalu memenuhi KKM

4. Ranking minimal masuk 10 besar kelas

5. Mempunyai prestasi lain

b. Keberhasilan program pendidikan karakter

Adapun keberhasilan pendidikan karakter dapat diukur dengan (Triana, 2013):

1. Mengamalkan ajaran agama yang dianut sesuai dengan tahap perkembangan remaja.

2. Memahami kekurangan dan kelebihan diri sendiri

3. Menunjukan sikap percaya diri

4. Mematuhi aturan-aturan sosial yang berlaku dalam lingkungan yang lebih luas.

5. Menghargai keberagaman agama, budaya, suku, ras dan golongan sosial ekonomis dalam lingkup nasional.

6. Mencari dan menerapkan informasi dari lingkungan sekitar dan sumber-sumber lain secara logis, kritis dan kreatif.

7. Menunjukan kemampuan berpikir logis, kritis, dan inovatif.

8. Menujukan kemampuan belajar secara mandiri sesuai dengan potensi yang dimiliki.

9. Menunjukan kemampuan menganalisis dan memecahkan masalah dalam kehidupan sehari-hari.

10. Mendeskripsikan gejala alam dan sosial.

11. Memanfaatkan lingkungan secara bertanggung jawab.

12. Menerapkan nilai-nilai kebersamaan dalam kehidupan bermasyarakat, berbangsa dan bernegara demi terwujudnya persatuan dan kesatuan R.I

13. Menghargai karya seni dan budaya nasional

14. Menghargai tugas pekerjaan dan memiliki kemampuan untuk berkarya

15. Menerapkan hidup bersih, sehat, bugar, aman dan memanfaatkan waktu luang dengan baik.

16. Berkomunikasi dan berinteraksi secara efektif dan santun

17. Memahami hak dan kewajiban diri dan orang lain dalam pergaulan di masyarakat, menghargai adanya perbedaan pendapat.

18. Menunjukan kegemaran membaca dan menulis naskah pendek sederhana.

19. Menunjukan ketrampilan menyimak, berbicara, membaca dan menulis dalam Bahasa Indonesia dan Bahasa Inggris

20. Menguasai pengetahuan yang diperlukan untuk mengikuti pendidikan menengah

21. Memiliki jiwa kewirausahaan

\section{METODOLOGI}

\section{Populasi Dan Sampel}

Dalam penelitian ini populasinya adalah IRT di lingkungan Semarang Tengah dengan sampel diambil secara random sampling. Jumlah sample diperoleh dengan menggunakan rumus slovin .

\section{Metode Pengumpulan Data}

Data yang akan dikumpulkan adalah data primer, yang dikumpulkan dengan menggunakan kuesioner untuk mengumpulkan data Intellectual Capital pada Ibu Rumah Tangga, Keberhasilan Pendidikan Anak dan Social Capital. 
Sedangkan data sekunder adalah data masyarakat semarang Tengah yang diambil dari data kependudukannya.

\section{Analisis regresi}

Analisis ini digunakan untuk menguji pengaruh Intellectual Capital pada Ibu Rumah Tangga terhadap Keberhasilan Pendidikan Anak dengan Social Capital sebagai Variabel Moderating.

Adapun model regresinya adalah sebagai berikut :

$\mathrm{Y}=\alpha+\beta 1 \mathrm{X} 1+\beta 2 \mathrm{X} 2+\beta 3 \mathrm{X} 1 \mathrm{X} 2+\varepsilon$

Dimana :

$\mathrm{Y}=$ Keberhasilan Pendidikan Anak

$\alpha \quad=$ Konstanta

$\beta 1-3=$ Koefisien regresi

$\mathrm{X} 1=$ Intellectual Capital pada $\mathrm{Ibu}$ Rumah Tangga

$\mathrm{X} 2$ = Social Capital pada Ibu Rumah

Tangga

\section{Uji Validitas dan Reliabilitas}

Uji ini perlu dilakukan untuk memastikan bahwa alat untuk mengumpulkan data cukup valid sehingga dapat digunakan untuk mengukur seluruh variabel penelitian yang digunakan dan pihak yang menggunakan tidak mengalami kerancuan persepsi dalam menterjemahkan pertanyaan dan jawaban yang harus diisikan. Apabila alat sudah dinyatakan valid dan reliabel, maka selanjutnya dapat dipergunakan untuk mengumpulkan data.

\section{Uji Asumsi Klasik}

Uji asumsi klasik yang digunakan dalam penelitian ini meliputi : Uji normalitas, untuk menguji apakah variabel pengganggu atau residual memiliki distribusi noramal. Kemudian uji Multikolinearitas, untuk menguji apakah model regresi ditemukan adanya korelasi antar variabel bebas. Kemudian uji Heterokedastisitas, untuk menguji apakah model regresi terjadi ketidaksamaan variance dari residual satu pengamatan ke pengamatan yang lain.

\section{Uji signifikansi Simultan (Uji F)}

Uji ini dilakukan untuk mengetahui apakah semua variabel independen atau bebas mempunyai pengaruh secara bersama terhadap variabel terikat. Dan juga untuk menguji kebaikan model.

\section{Uji Koefisien Determinasi (Adjusted $\mathbf{R}$ Square)}

Uji ini mengukur seberapa kemampuan model dalam menerangkan variasi variabel terikat oleh variabel bebasnya.Nilai yang mendekati 1 berarti vriabel-variabel bebas memberikan hampir semua informasi yang dibutuhkan untuk memprediksi variabel bebas.

\section{Uji signifikansi Parsial (Uji t)}

Uji t untuk menguji seberapa jauh pengaruh suatu variabel terikat secara individual terhadap variabel dependen.

\section{HASIL DAN PEMBAHASAN}

\section{Hasil Pemilihan Sampel dan Data Responden}

Berdasarkan data yang diperoleh pada kantor kecamatan Semarang Tengah diperoleh data ibu rumah tangga sebanyak 149 orang. Sampel ditentukan menggunakan rumus slovin sehingga didapat hasil 108 sampel yang dibutuhkan. Responden yang dipilih merupakan ibu rumah tangga yang memiliki anak usia sekolah tingkat dasar $\begin{array}{llll}\text { yaitu SD dan } & \text { SMP. }\end{array}$ 
Setelah penyebaran kuesioner dilakukan didapat data responden berdasarkan pendidikan terakhir, sebagai berikut:

\section{Tabel 1. Tingkat Pendidikan Responden}

\begin{tabular}{cc}
\hline Pendidikan Terakhir & Jumlah \\
\hline S1 & 1 \\
D3 & 3 \\
D1 & 2 \\
SMA & 37 \\
SMEA & 8 \\
SMK & 7 \\
SMP & 38 \\
SD & 12 \\
\hline Total & 108 \\
\hline
\end{tabular}

Berdasarkan hasil pada tabel di atas, responden memiliki pendidikan terendah SD dan tertinggi S1. Responden terbanyak berpendidikan terakhir SMP yaitu sebanyak 38 orang dan jumlah yang paling sedikit adalah responden dengan pendidikan terakhir S1 sebanyak 1 orang. Apabila dipersentasekan maka responden dengan tingkat pendidikan dasar sebesar 46\%, tingkat pendidikan menengah $48 \%$ dan tingkat pendidikan tinggi sebesar $6 \%$.

Tabel 2. Persentase Tingkat Pendidikan Responden

\begin{tabular}{lrr}
\hline Tingkat Pendidikan & Jumlah & Persentase \\
\hline $\begin{array}{l}\text { Dasar (sampai } \\
\text { dengan SMP) }\end{array}$ & 50 & $46 \%$ \\
$\begin{array}{l}\text { Menengah (SMA } \\
\text { sederajat) }\end{array}$ & 52 & $48 \%$ \\
$\begin{array}{l}\text { Tinggi (Diploma, } \\
\text { sarjana) }\end{array}$ & 6 & $6 \%$ \\
\hline & 108 & $100 \%$ \\
\hline
\end{tabular}

Responden juga diidentifikasi berdasarkan lamanya menikah. Hal ini dimaksudkan untuk melihat pengalaman responden dalam mendidik anak. Hasilnya didapat bahwa responden dengan jumlah terbanyak 14 orang memiliki pengalaman menikah 14 tahun dan 15 tahun. Responden dengan pengalaman menikah paling lama yaitu 42 tahun sebanyak 1 orang. Responden dengan pengalaman menikah paling sedikit yaitu 9 tahun sebanyak 1 orang.

\section{Tabel 3. Umur Pernikahan Responden}

\begin{tabular}{|c|c|}
\hline Lamanya menikah & Jumlah \\
\hline 9 & 1 \\
\hline 10 & 3 \\
\hline 11 & 5 \\
\hline 12 & 4 \\
\hline 13 & 12 \\
\hline 14 & 5 \\
\hline 15 & 14 \\
\hline 16 & 14 \\
\hline 17 & 11 \\
\hline 18 & 4 \\
\hline 19 & 6 \\
\hline 20 & 3 \\
\hline 21 & 2 \\
\hline 22 & 3 \\
\hline 23 & 5 \\
\hline 24 & 2 \\
\hline 25 & 1 \\
\hline 26 & 4 \\
\hline 27 & 2 \\
\hline 31 & 2 \\
\hline 32 & 1 \\
\hline 35 & 3 \\
\hline 42 & 1 \\
\hline Total & 108 \\
\hline
\end{tabular}

\section{Uji Validitas dan Reliabilitas Butir Pertanyaan}

a. Hasil Uji Validitas

Hasil uji validitas dengan melihat nilai Pearson Correlation dan juga besarnya nilai 
signifikannya. Apabila nilai Pearson Correlation positif dan signifikansinya dibawah 0.05 maka butir pertanyaan dinyatakan lolos uji validitas. Berdasarkan hasil uji validitas terhadap butir pertanyaan kuesioner dalam penelitian ini didapatkan hasil bahwa nilai Pearson Correlation secara keseluruhan bernilai positif dan nilai signifikannya kurang dari 0,05. Maka dapat disimpulkan bahwa seluruh butir pertanyaan kuesioner dalam penelitian ini dinyatakan lolos uji validitas. Hasil uji tersebut dapat dilihat dalam lampiran. Hasil Uji Reliabilitas

Hasil uji reliabilitas yang dilakukan terhadap butir pertanyaan, didapat bahwa variabel Intellectual Capital, Social Capital, dan Keberhasilan Pendidikan Anak memiliki Cronbach's Alpha lebih dari 0,6 maka konstruk tiap variabel dinyatakan reliable.

Tabel 4. Hasil Uji Reliabilitas

\begin{tabular}{lr}
\hline \multicolumn{1}{c}{ Variabel } & Cronbach's Alpha \\
\hline Intellectual Capital & 0,773 \\
Social Capital & 0,722 \\
Keberhasilan & 0,792 \\
Pendidikan Anak & \\
\hline
\end{tabular}

\section{Hasil Uji Asumsi Klasik}

a. Normalitas

Pada hasil uji normal probability plots, titik-titik mengikuti garis diagonal dari titik 0 dan tidak melebar terlalu jauh, maka dapat disimpulka data berdistribusi normal.

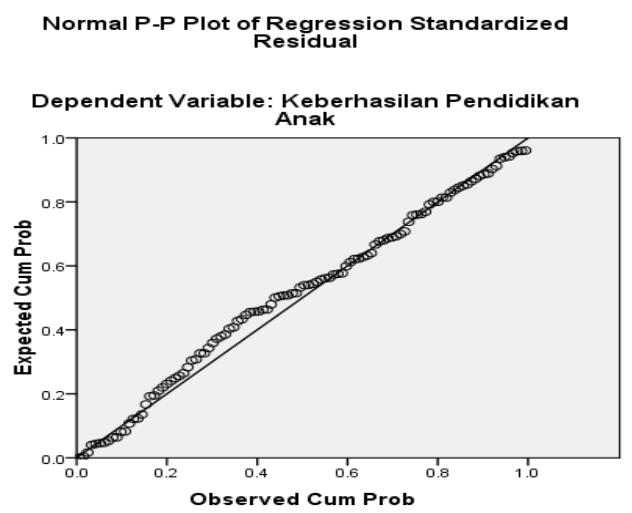

b. Heteroskedastisitas

Pada hasil uji heteroskedastisitas didapatkan hasil titik-titik menyebar dan tidak membentuk pola tertentu. Hal ini berarti tidak terjadi heteroskedastisitas data.

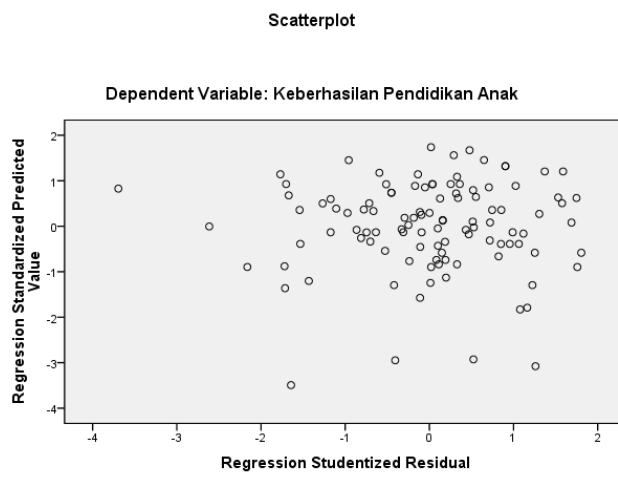

c. Multikolinearitas

Hasil uji multikolinearitas dilakukan pertama dengan didapatkan hasil bahwa VIF lebih besar dari 10 dan nilai toleransinya kurang dari 0.1 seperti pada tabel di bawah. Hal ini dapat diartikan bahwa data tidak lolos multikolinearitas.

Tabel 5. Hasil Uji Multikolinearitas

\begin{tabular}{lrr}
\hline & \multicolumn{2}{c}{$\begin{array}{c}\text { Collinearity } \\
\text { Statistics }\end{array}$} \\
\cline { 2 - 3 } & Tolerance & \multicolumn{1}{c}{ VIF } \\
\hline Intelectual Capital & 0,015 & 67,181 \\
Social Capital & 0,016 & 63,561 \\
Moderating1 & 0,006 & 173,197 \\
\hline
\end{tabular}

Karena hal tersebut, maka dilakukan uji multikolinearitas kembali dengan Ln Variabel. Hasilnya terdapat Excluded Variables. Excluded Variable adalah variabel yang dikeluarkan dari analisis yaitu variabel Intelectual Capital. Variabel Social Capital dan Variabel Moderasi memiliki nilai toleransi lebih dari 0,1 dan nilai VIF kurang dari 10 maka kedua variabel tersebut dinyatakan lulus uji multikolinearitas. 


\section{Coefficients $^{\mathrm{a}}$}

\begin{tabular}{|c|c|c|c|}
\hline \multirow{2}{*}{ Model } & \multirow[t]{2}{*}{ Sig. } & \multicolumn{2}{|c|}{$\begin{array}{c}\text { Collinearity } \\
\text { Statistics }\end{array}$} \\
\hline & & Tolerance & VIF \\
\hline (Constant) & 0 & & \\
\hline $1 \begin{array}{l}\text { Ln_Social } \\
\text { Capital }\end{array}$ & 0.024 & 0.351 & 2.849 \\
\hline Ln_Moderasi & 0.005 & 0.351 & 2.849 \\
\hline
\end{tabular}

a. Dependent Variable: Ln_Y

\section{Excluded Variables $^{\mathrm{b}}$}

\begin{tabular}{|c|c|c|c|}
\hline \multirow[b]{2}{*}{ Model } & \multicolumn{3}{|c|}{ Collinearity Statistics } \\
\hline & $\begin{array}{c}\text { Toleranc } \\
\text { e }\end{array}$ & $\begin{array}{l}\text { VI } \\
\text { F }\end{array}$ & $\begin{array}{l}\text { Minimu } \\
\mathrm{m} \\
\text { Toleranc } \\
\mathrm{e}\end{array}$ \\
\hline $\begin{array}{l}\text { Ln_Intelectu } \\
\text { al Capital }\end{array}$ & 0 & & 0 \\
\hline
\end{tabular}

a. Predictors in the Model: (Constant), Ln_Moderasi, Ln_Social Capital

b. Dependent Variable: Ln_Y

\section{Analisis Pengaruh dan Pembahasan}

Hasil uji regresi untuk mengukur pengaruh Intelectual Capital terhadap Keberhasilan Pendidikan Anak dengan Social Capital sebagai variabel moderasi didapatkan hasil bahwa setelah dilakukan uji asumsi klasik yaitu uji muktikolinearitas terdapat Excluded Variables.

Tabel 6. Hasil Uji Regresi Linear

\begin{tabular}{lcr}
\hline Model & B & \multicolumn{1}{r}{ Sig. } \\
\hline (Constant) & 1,160 & 0 \\
Ln_Social Capital & 0,131 & 0.024 \\
Ln_Moderasi & 0,134 & 0.005
\end{tabular}

Berdasarkan tabel hasil uji regresi diatas maka persamaan regresi yang didapat adalah $Y=1,160+0,131 X_{2}+0,134 X_{1} X_{2}+\epsilon$

Koefisien determinasi Adjusted $R$ Square (Adj. $\mathrm{R}^{2}$ ) sebesar 0,354, artinya sebesar 35,4 persen variasi perubahan variabel Keberhasilan Pendidikan Anak dapat dijelaskan oleh variasi perubahan variabel Social Capital dan variabel moderasi_ $\mathrm{X}_{1} \mathrm{X}_{2}$, sedangkan 64,6 persen dapat dijelaskan oleh variabel-variabel lain yang tidak diteliti.

Tabel 7. Uji Pengaruh

\begin{tabular}{cccc}
\hline $\mathrm{R}$ & $\begin{array}{c}\mathrm{R} \\
\text { Square }\end{array}$ & $\begin{array}{c}\text { Adjusted } \\
\mathrm{R} \\
\text { Square }\end{array}$ & $\begin{array}{c}\text { Std. Error } \\
\text { of the } \\
\text { Estimate }\end{array}$ \\
\hline $0,667^{\mathrm{a}}$ & 0,471 & 0,354 & 1.08504 \\
\hline
\end{tabular}

Pengujian signifikansi pengaruh variabel independent dan moderasi terhadap variabel dependent secara simultan menggunakan uji $\mathrm{F}$ dengan hasil sebagai berikut:

Tabel 8. Uji simultan

\begin{tabular}{cc}
\hline F & Sig. \\
\hline 24,035 & $0,021^{a}$ \\
\hline
\end{tabular}

Hasil uji $\mathrm{F}$ menggunakan taraf signifikansi $5 \%(0,05)$, nilai probabilitas nya $<0,05$, maka dapat dikatakan terdapat pengaruh yang signifikan secara bersama-sama antara variabel Social Capital dan variabel moderasi_ $\mathrm{X}_{1} \mathrm{X}_{2}$ terhadap variabel Keberhasilan Pendidikan Anak.

Pengujian signifikansi pengaruh variabel independent dan moderasi terhadap variabel dependent secara parsial menggunakan uji t, dengan hasil sebagai berikut: 
Tabel 9. Uji Parsial

\begin{tabular}{lrcr}
\hline & $\mathrm{t}$ hitung & $\mathrm{t}$ tabel & \multicolumn{1}{c}{ Sig. } \\
\hline (Constant) & 11.054 & 1,98 & 0 \\
$\begin{array}{l}\text { Ln_Social } \\
\text { Capital }\end{array}$ & 3.223 & 1,98 & 0.024 \\
Ln_Moderasi & 2.534 & 1,98 & 0.005 \\
\hline
\end{tabular}

probabilitas nilai $\mathrm{t}$ atau signifikansi $<0,05$ dan nilai $\mathrm{t}$ tabel $<\mathrm{t}$ hitung, maka dapat dikatakan bahwa terdapat pengaruh antara Social Capital dan variabel moderasi_ $\mathrm{X}_{1} \mathrm{X}_{2}$ terhadap variabel Keberhasilan Pendidikan Anak.

Berdasarkan hasil uji yang telah dilakukan maka hipotesis pada penelitian ini yang menyatakan bahwa diduga terdapat Pengaruh Intellectual Capital pada Ibu Rumah Tangga terhadap Keberhasilan Pendidikan Anak dengan Social Capital sebagai Variabel Moderating ditolak. Hal ini dikarenakan dalam pengujian ternyata variabel Intellectual Capital merupakan Excluded Variables. Hal ini bisa saja disebabkan karena butir konstruk yang digunakan kurang menggambarkan variabel Intellectual Capital pada Ibu Rumah Tangga. Apabila dilihat dari latarbelakang responden, jumlah responden sebagian besar merupakan ibu rumah tangga dengan tingkat pendidikan dasar sehingga kemungkinan belum memiliki pengalaman pribadi dalam hal menempuh ataupun memilih pendidikan menengah ataupun tinggi.

Terdapat $46 \%$ responden dengan tingkat pendidikan dasar, artinya hampir separuh dari total responden belum pernah menempuh pendidikan menengah sehingga pengalaman untuk memilih pendidikan anaknya ke jenjang menengah dan tinggi tidak dapat mengandalkan dari pengalaman pribadi. Hasil uji menunjukan bahwa Social Capital berpengaruh terhadap Keberhasilan Pendidikan Anak dan mampu memoderasi variabel Intellectual Capital. Hal ini dapat diartikan bahwa responden mengandalkan Social Capital yang dimilikinya untuk menunjang Intellectual Capital yang terbatas demi keberhasilan pendidikan anakanaknya. Bisa dilakukan dengan mencari informasi, berbagi pengalaman, meminta bantuan lewat jaringan sosial responden.

Berdasarkan hasil penelitian ini dapat disimpulkan bahwa Intelectual Capital yang dimiliki oleh seorang ibu bukan satu-satunya penentu keberhasilan pendidikan anak. Seorang ibu yang memiliki Intelectual Capital terbatas sebaiknya meningkatkan Social capital terutama dalam hal jaringan sosial apabila ingin pendidikan anaknya lebih baik. Begitu pula dengan ibu yang telah memiliki Intelectual Capital yang cukup bahkan tinggi, akan semakin berhasil pendidikan anaknya apabila ditunjang dengan semangat ibu untuk meningkatkan Social Capitalnya.

\section{KESIMPULAN DAN SARAN}

\section{Kesimpulan}

Berdasarkan hasil penelitian ini dapat disimpulkan bahwa Intelectual Capital ibu rumah tangga tidak berpengaruh terhadap keberhasilan pendidikan anak dengan Social Capital sebagai variabel moderasi. Keberhasilan pendidikan anak justru dipengaruhi oleh Social Capital ibu rumah tangga. Oleh karena itu, ibu rumah tangga perlu meningkatkan Social Capital yang dimiliki apabila menginginkan keberhasilan pendidikan bagi anak-anaknya.

\section{Saran}

Apabila melihat dari hasil penelitian, maka saran untuk penelitian selanjutnya adalah memperbaiki konstruk yang dijadikan dasar dalam membuat butir pertanyaan serta menambahkan data primer berupa wawancara langsung agar hasil 
penelitian lebih jelas menggambarkan keadaan sebenarnya dilapangan.

\section{DAFTAR PUSTAKA}

Alfiasari, Hastuti Dwi, Penguatan Modal Sosial untuk Perlindungan Sosial rumah Tangga Miskin dalam Mengoptimalkan Status Gizi dan Kematangan Sosial Anak, Departemen Ilmu Keluarga dan Konsumen Fakultas Ekologi Manusia, IPB, Child Poverty and Social protection Conference, 2011.

Andi, Hasil Pokok Pendidikan, Jendela, 2012.

http://kbbi.web.id/ibu

Salwinsah, Peranan Orang Tua, Sekolah dan Guru dalam mensukseskan Pendidikan Anak, Jendela Hati, 2012.

Superi, Persepsi Ibu Rumah Tangga tentang HIV/AIDS di Desa Kori Kecamatan Sawono Kabupaten Ponorogo, Universitas Muhammadiyah, Ponorogo, 2013.

Triana, Indikator Keberhasilan Pendidikan Karakter, 2013

Sawarjuwono, T. And A.P. Kadir (2003), Intellectual Capital : Recognation, Measurement and Reporting (Library Research), Journal of Accountancy and Financial, vol 5, no. 1 pp:35-57.

Williams,S,M. (2001), Is Intellectual Capital Performance and DisclosurenPractice Related?, Journal of Intellectual Capital, Vol 2, No 3.

Ghozali, Imam (2006), Aplikasi Analisis Multivariate dengan Pro ram SPSS, Semarang: Badan Penerbit Universitas Diponegoro 